WARSZTATY Z GEOGRAFII TURYZMU

ISBN 978-83-7969-138-8 $\quad$ s. $175-185$

http://dx.doi.org/10.18778/7969-138-8.12

Natalia KRAWCZYSZYN

Uniwersytet Ekonomiczny we Wrocławiu

Wydział Ekonomii, Zarządzania i Turystyki w Jeleniej Górze

\title{
SIECIOWE PRODUKTY TURYSTYCZNE JAKO PRZEDMIOT WSPÓŁPRACY W EUROREGIONACH POLSKO-CZESKICH
}

\section{Wstęp}

Turystyczny produkt sieciowy to całościowy pakiet złożony z usług świadczonych w przestrzeni atrakcyjnej turystycznie, wiążący obiekty, atrakcje, produkty regionalne i lokalne, trasy turystyczne oraz wiele innych elementów, na bazie spójnej koncepcji. Koncepcja produktu sieciowego jest jego głównym wyróżnikiem. Jej trzon stanowi marka, pod którą produkt jest oferowany na rynku i za pomocą której jest identyfikowany przez klientów. Sieci w turystyce są odpowiedzią na zmieniające się potrzeby społeczeństwa. Współczesny turysta docenia bowiem możliwość korzystania z usług w postaci zbiorczej, a także wymaga oferowania produktu unikatowego, interesującego i pełnego, który zaspokoi jego zaawansowaną potrzebę poznawania świata. Z punktu widzenia przedsiębiorców sektora turystycznego, działanie w sieci otwiera wiele możliwości rozwoju i zwiększenia atrakcyjności oferty, a tym samym konkurencyjności całego przedsiębiorstwa.

Sieci turystyczne już od lat funkcjonują np. w branży hotelarskiej, gdzie międzynarodowe sieci hotelowe zastosowały standaryzację ułatwiającą turyście identyfikację obiektów hotelowych dzięki wspólnej, globalnej marce. Produkty turystyczne sieciowe, rozumiane jako zbiór korzyści dla klienta, będące łatwo przez niego identyfikowalne oraz atrakcyjniejsze od poje- 
dynczych usług są nieco innym zjawiskiem. Przede wszystkim ze względu na fakt, że łączą przedsiębiorców działających indywidualnie, potencjalnie oferujących produkty nie tylko komplementarne, ale także substytucyjne. Forma współpracy tego typu, łącząca wynikającą z działania w jednej branży rywalizację ze współpracą w celu uzyskania wartości dodanej (zarówno dla samych uczestników sieci, ale także dla klientów - turystów) to koopetycja. Jej sprawne funkcjonowanie przejawia się w fakcie, iż wszystkie strony uczestniczące we współpracy odczuwają realne korzyści z niej płynące i tym samym poniesione koszty uczestnictwa w sieci (wkład) są rekompensowane z satysfakcjonującą nadwyżką. Ma tu miejsce specyficzne zjawisko osiągania korzyści przez wszystkich uczestników wymiany: win-woin-win (Science meets business, 2013). Należy przy tym zauważyć, że nie wszystkie korzyści z sieci są łatwo mierzalne. Część z nich, np. umocnienie wizerunku przedsiębiorstwa czy zwiększenie rozpoznawalności marki w branży, znacząco, lecz pośrednio, wpływają na sukces firmy w dłuższym okresie.

\section{Pogranicze polsko-czeskie}

Transgraniczna przestrzeń badawcza, tj. obszar euroregionów polsko-czeskich ze szczególnym uwzględnieniem euroregionów Glacensis i Pradziad, która została wybrana do niniejszych rozważań dotyczących sieciowych produktów turystycznych, posiada wiele specyficznych cech. Charakterystyka obszaru pozwala stwierdzić, że szczególnie wyróżnia się on na tle innych regionów turystycznych w Polsce pod względem istniejących tu uwarunkowań rozwoju turystyki, rodzaju zagospodarowania turystycznego i narzędzi wspierających realizację turystycznych produktów sieciowych o charakterze transgranicznym. Istniejące euroregiony polsko-czeskie: Glacensis, Pradziad, Śląsk Cieszyński, Silesia, Nysa i Beskidy, to obszary rozwinięte turystycznie. Spośród nich pod względem realizacji funkcji turystycznej znacząco wyróżniają się dwa pierwsze. Należy zauważyć, że przygraniczne położenie obszaru badań sprzyja rozwijaniu ruchu turystycznego mimo naturalnej peryferyjności, m.in. dzięki zaoferowaniu turyście możliwości uprawiania turystyki transgranicznej w przyjaznej formie - w sposób odgórnie uporządkowany, czytelny, łatwo osiągalny (np. niwelujący barierę językową czy kulturową), specjalnie przygotowany i pakietowany - dostosowany do potrzeb turysty poszukującego rozwiązań nieabsorbujących jego czasu wolnego przy 
planowaniu, ale mimo to atrakcyjnych i urozmaiconych. Pogranicze polskoczeskie to przestrzeń zróżnicowana, podzielona granicą (w dobie integracji europejskiej mającą coraz mniejsze znaczenie), językiem, poziomem zagospodarowania, lecz połączona walorami środowiska przyrodniczego czy historią. Występujące na badanym obszarze krajobrazy górskie i podgórskie (m.in. w ramach obszarów chronionych, np. Karkonoskiego Parku Narodowego), wody mineralne (m.in. Jańskie Łaźnie i Jesenik w Czechach, uzdrowiska kłodzkie w Polsce) i obiekty kultury materialnej (m.in. pozostałości twierdz pruskich, zabytkowe centra miast, muzea, pomniki) sprzyjają rozwojowi funkcji turystycznej (PANASIEWICZ 1999). Właśnie z tego względu podstawą gospodarki po obu stronach granicy w rejonach górskich jest obsługa ruchu turystycznego. Zważywszy na fakt, że współpraca w ramach sieci kooperacyjnych jest korzystna, zwłaszcza w sektorach, gdzie dominują mikro- i małe przedsiębiorstwa, networking ( $\mathrm{z}$ ang. sieciowanie) jest $\mathrm{w}$ nich szczególnie chętnie wykorzystywany. Sieci mogą mieć charakter lokalny, ale często obejmują szerszy zasięg: regionalny, ponadregionalny, a nawet międzynarodowy. Realizacja działań sieciowych w ramach polsko-czeskiej współpracy transgranicznej przyczynia się do realizacji idei integracji społecznej, ekonomicznej i przestrzennej w ramach Unii Europejskiej. Projektując tego typu przedsięwzięcia partnerzy po obu stronach granicy skutecznie pozyskują środki pomocowe UE w ramach Europejskiej Współpracy Terytorialnej. Dzięki dofinansowaniu unijnemu powstało wiele turystycznych transgranicznych produktów sieciowych, których funkcjonowanie na rynku turystycznym można aktualnie obserwować. Początki współfinansowania polsko-czeskich produktów turystycznych sięgają programu Phare i utworzonego w jego ramach Programu Współpracy Przygranicznej - Phare CBC (1999-2003). Kolejnym etapem po akcesji Rzeczpospolitej Polskiej do UE było uruchomienie programu Interreg III (2004-2006), komponentu A (współpraca transgraniczna). Od roku 2007 oba kraje członkowskie korzystają ze wsparcia w ramach Europejskiej Współpracy Terytorialnej - Programu Operacyjnego Współpracy Transgranicznej Republika Czeska - Rzeczpospolita Polska (2007-2013) (KRAWCZYSZYN 2012). Szczególną popularnością wśród realizowanych na pograniczu polsko-czeskim projektów turystycznych cieszą się dotyczące promocji, wydawnictw turystycznych oraz informacji turystycznej (m.in. wydawnictwa przewodnikowe, unowocześnianie punktów informacji, realizacja stron internetowych), a także infrastrukturalne (szlaki turystyczne, ścieżki rowerowe) oraz związane z wydarzeniami (transgraniczne imprezy rekreacyjne i turystyczne) (KRAWCZYSZYN 
2012). W 2014 r. rozpoczął się nowy okres programowania UE (2014-2020), którego kształt zdeterminuje powstawanie nowych projektów, w tym sieciowych produktów turystycznych o charakterze transgranicznym. $W$ ramach studium przypadku w dalszej części artykułu przeanalizowane zostaną dwie zrealizowane w latach 2008-2011 sieci o charakterze transgranicznym, które funkcjonują do dziś.

\section{Nowe marki polsko-czeskiego pogranicza - "Citywalk" i „Fortfan"}

Marki „Citywalk” i „Fortfan” są interesującym przykładem realizacji idei turystycznych produktów sieciowych. Bazują na podstawowych wyróżnikach obszaru pogranicza polsko-czeskiego - atutach, które na etapie opracowywania projektów zostały zidentyfikowane i wyselekcjonowane przez partnerów po obu stronach granicy. Pierwszym wyróżnikiem jest atrakcyjne dziedzictwo kulturowe miast - "Citywalk", drugim zaś tradycje dawnych twierdz pruskich - „Fortfan” (KRAWCZYSZYN 2011). Rzeczywiste efekty zaistnienia wymienionych marek na pograniczu polsko-czeskim są trudno mierzalne, co wynika ze specyfiki turystyki jako dziedziny gospodarki. Jednak z punktu widzenia wizerunku posiadanie rozbudowanej oferty dla turystów podnosi atrakcyjność obszaru recepcji turystycznej poprzez wzrost jego „użyteczności turystycznej”. Użyteczność jest w tym wypadku rozumiana jako możliwość wykorzystania istniejących walorów i atrakcji turystycznych na potrzeby ruchu turystycznego wiążąca się ściśle z poziomem istniejącego zagospodarowania turystycznego, bogactwem oferty turystycznej, zaawansowaniem w zakresie sprzedaży produktu turystycznego. Jest to pewnego rodzaju komercjalizacja produktu turystycznego, jednak wyróżniająca się istotnymi cechami - oferowaniem atrakcji podpartych solidną podstawą rzeczywiście atrakcyjnych turystycznie elementów, nie zaś budowaniem elementów zagospodarowania turystycznego niepopartych stosownymi walorami środowiska przyrodniczego albo takich, których istnienie na danym obszarze nie tylko w żaden sposób nie wzbogaca istniejącego dziedzictwa, ale wprost ingeruje $\mathrm{w}$ jego dotychczasową funkcję i burzy ład przestrzenny.

Mimo braku możliwości zmierzenia rzeczywistych efektów wprowadzenia na pograniczu polsko-czeskim marek turystycznych obecnie można już określić zmiany, jakie zaistniały bądź prawdopodobnie zaistnieją w przy- 
szłości w gospodarce turystycznej badanego obszaru. Studium przypadku marek "Citywalk” oraz "Fortfan” pozwala zauważyć, jak - wraz z powstaniem inicjatywy projektów sieciowych w turystyce - zmienia się sposób świadczenia i zakres usług turystycznych na pograniczu polsko-czeskim (KRAWCZYSZYN 2011).

\section{Marka "Citywalk"}

Projekt „Miejskie trasy turystyczne zintegrowanym produktem turystycznym miast czesko-polskiego pogranicza" połączył sześciu partnerów po obu stronach polsko-czeskiej granicy: Kłodzko (partner wiodący), Świdnicę, Bardo, Kędzierzyn Koźle po stronie polskiej oraz Česką Skalicę i Přerov po stronie czeskiej (serwis internetowy miejskich...) (rys. 1).

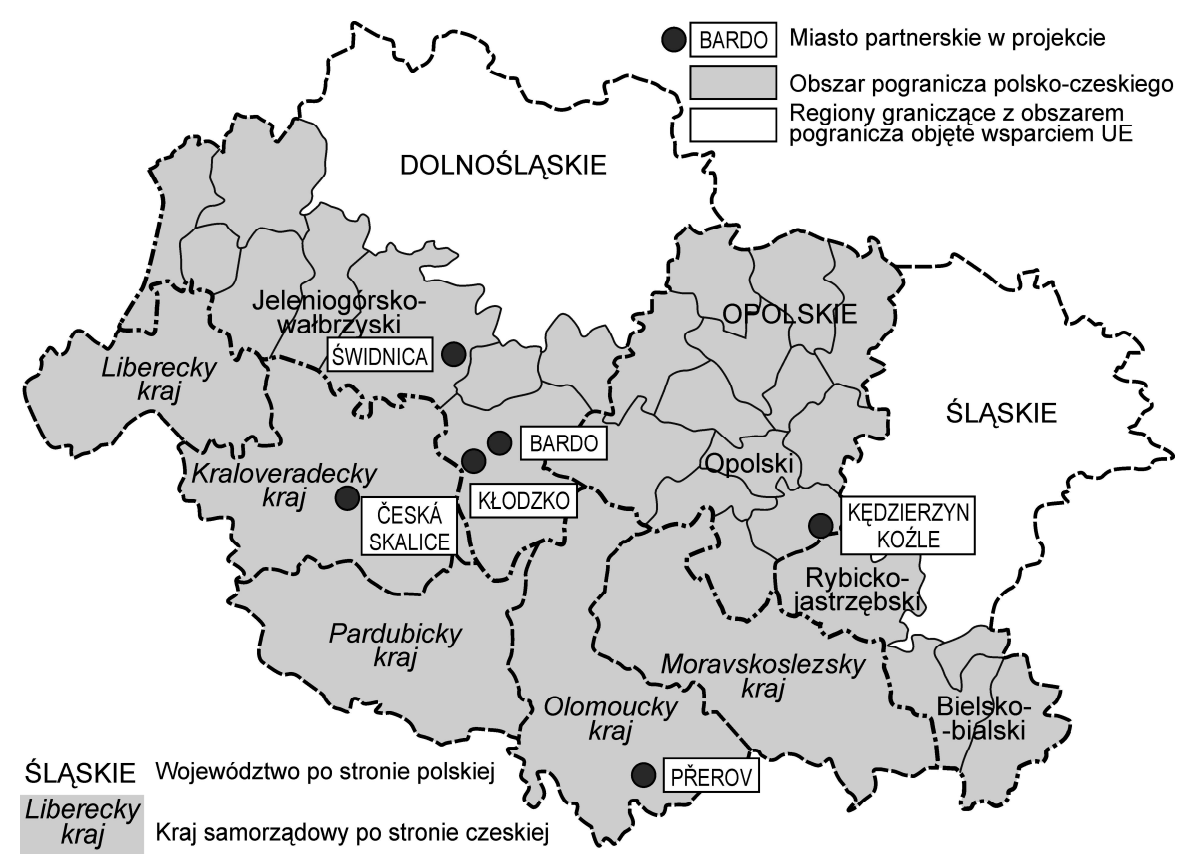

Rys. 1. Partnerzy projektu „Miejskie trasy turystyczne zintegrowanym produktem turystycznym miast czesko-polskiego pogranicza" (euroregiony Glacensis i Pradziad)

Źródło: Program Operacyjny....; modyfikacje własne, za N. KRAWCZYSZYN ( 2011) 
Ideą projektu było utworzenie $\mathrm{w}$ transgranicznej sieci turystycznych szlaków miejskich, które obejmą jak najwięcej ciekawych kulturowo miast. W początkowym stadium, objętym dofinansowaniem w ramach POWT Republika Czeska - Rzeczpospolita Polska, sześć miast miało rozpowszechnić ideę "Citywalk". Kolejnym etapem ma być rozszerzanie zasięgu marki o nowe miasta. W 2013 r. chęć włączenia w sieć „Citywalk” zadeklarowały kolejne dwa miasta - Rychnov nad Kněžnou oraz Świebodzice. Miasta partnerzy - twórcy marki - stworzyły ogólną koncepcję szlaków miejskich wyposażonych w nowoczesne rozwiązania technologiczne (audioprzewodniki, kioski multimedialne), własny system identyfikacji wizualnej oraz narzędzia promocji: multimedialne stoisko targowe, artykuły prasowe, internetowe, study tour dla dziennikarzy, foldery promocyjne i minimapki oraz bogato ilustrowany przewodnik po wszystkich sześciu miastach projektu (patrz: Standardowy wniosek... 2008). Nie są znane dokładne efekty wprowadzenia marki "Citywalk". Statystyki ruchu turystycznego nie odnotowują bowiem zmian w ruchu turystycznym spowodowanych jednym, określonym czynnikiem. W jednym z miast partnerskich - Świdnicy, liczba wypożyczeń audioprzewodników na przestrzeni lat 2011-2013 (do końca sierpnia) wyniosła 1925 sztuk. Nie można jednak tego typu danych uznać za miarodajne, ponieważ audioprzewodniki są jednym z wielu elementów całego projektu i niewielka część turystów penetrujących miejską trasę turystyczną z nich korzysta. Kontakty między miastami zaangażowanymi w markę "Citywalk", podtrzymywane przez okres czterech lat obejmujących przygotowanie i realizację projektu, utworzyły silne więzi, które będą wykorzystywane w przyszłości przy realizacji kolejnych polsko-czeskich inicjatyw. Podjęto już starania o kontynuację projektu - rozszerzenie jego funkcjonalności i zasięgu, która jednak ze względu na znaczną kapitałochłonność formułowana jest jako kolejne wnioski o dofinansowanie w ramach EWT. Sieciowy produkt turystyczny - marka "Citywalk” objął w Polsce dwa województwa i cztery powiaty, zaś w Czechach - dwa województwa oraz dwa powiaty. Pobudzenie rozwoju współpracy w branży turystycznej pogranicza polsko-czeskiego miało na celu stworzenie podwalin dla pewnego rodzaju klastra turystycznego, który następnie powinien rozwijać się samoistnie w oparciu o już istniejący, rozbudowany produkt (KRAWCZYSZYN 2011). Klaster charakteryzuje się budowaniem nie zawsze formalnych powiązań branżowych polegających na wymianie zarówno informacji, jak i wiedzy (PANASIUK 2006). Dla klastra turystycznego charakterystyczne są powiązania oparte głównie na zaufaniu, uczeniu się, uzupełnianiu oraz wzajemnym wsparciu (SZOSTAK 2006). 
Stworzenie klastra wymaga jednak również włączenia we wspólne działania jednostki naukowo-badawczej oraz realizacji transferu wiedzy. W przypadku marki "Citywalk” dalsze funkcjonowanie sieci miejskich tras turystycznych oraz ich rozbudowa została oparta o instytucje koordynujące rozwój turystyki w miastach - LOT-y, centra informacji turystycznej i inne. Dzięki temu marka "Citywalk" ma szansę funkcjonować bezterminowo i rozwijać się dzięki społecznościom lokalnym miast partnerów jako spójna sieć.

\section{Marka "Fortfan"}

Drugi projekt tworzący sieciową markę turystyczną „Rekonstrukcje historyczne wspólnym produktem turystycznym polsko-czeskiego pogranicza" zakładał organizację w latach 2008-2010 corocznych imprez będących widowiskami historycznymi, czyli rekonstrukcjami bitew z przeszłości miast pogranicza. Do projektu przystąpiło dziewięciu partnerów (partner wiodący Kłodzko, Świdnica, Nysa, Stoszowice, Kędzierzyn Koźle, Zlaté Hory, Králiky, Jaroměř) i stowarzyszenie Komitet w Sprawie Zachowania Pamiątek z Wojny w 1866 r. z siedzibą w Hradec Králové (serwis internetowy rekonstrukcji...) (rys. 2).

W każdej spośród dziewięciu miejscowości w kolejnych latach realizacji projektu odbyło się łącznie od jednej do trzech bitew pod szyldem „Fortfan”. Charakterystyczną cechą projektu była dbałość o odwzorowanie istotnych realiów historycznych (miejsca bitew, wyposażenie wojsk, scenografia). Imprezy miały na celu edukację dzieci i dorosłych, a także popularyzację historii miast będących niegdyś twierdzami pruskimi oraz dalsze rozwijanie współpracy poprzez generowanie przepływów turystów między polskimi i czeskimi miastami - partnerami projektu. Jak już wspomniano, wspólnym mianownikiem miast partnerskich pod marką „Fortfan” była lokalizacja na ich terenie (w przypadku stowarzyszenia na terenie ich działalności) pozostałości twierdz pruskich - obiektów dziedzictwa kulturowego Europy (KRAWCZYSZYN 2011). Ważnym elementem projektu było stworzenie wspólnego kalendarza imprez miejskich o charakterze rekonstrukcji historycznych, który był szeroko promowany przez wszystkie miasta partnerskie, drukowany na koszulkach promocyjnych i obecny w materiałach poligraficznych (ulotki, płyty promocyjne, spoty reklamowe $\mathrm{w}$ telewizji regionalnej). Tego typu działania ograniczają substytucyjność wydarzeń przyciągających tury- 
stów i pozwalają unormować ich przepływy pomiędzy miastami, dbając o zapewnienie im możliwości uczestnictwa w poszczególnych imprezach („eventach”) bez konieczności rezygnacji z innych. Połączenie imprez wspólną ideą pozwoliło na przepływ wiedzy, dobrych praktyk, a nawet uczestników: stowarzyszeń biorących udział w rekonstrukcjach oraz mieszkańców poszczególnych miast dowożonych autobusami w miejsca organizacji wydarzeń pomiędzy miastami partnerami. Ustalenie wspólnego kalendarza imprez pozwoliło również na szeroką promocję, której koszt rozłożył się równomiernie na wszystkich partnerów.

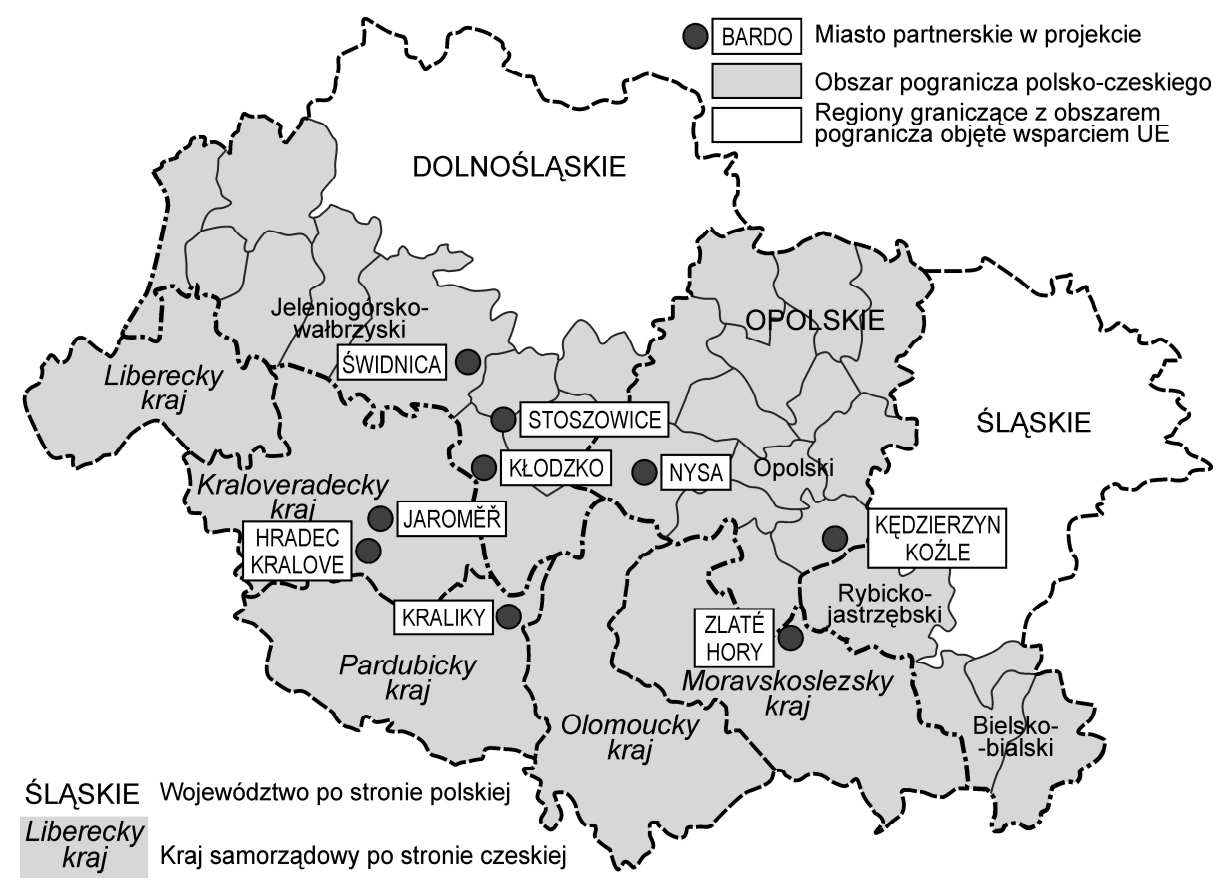

Rys. 2. Partnerzy projektu „Rekonstrukcje historyczne wspólnym produktem turystycznym” (w przypadku Stowarzyszenia „Komitet...” - siedziba) na pograniczu polsko-czeskim Źródło: Program Operacyjny....; modyfikacje własne, za N. KRAWCZYSZYN (2011)

Program lojalnościowy „Paszport Fortfana” to kolejny element projektu, który dzięki stworzeniu sieci partnerskiej był możliwy do zrealizowania wśród widzów. Stowarzyszenia rekonstrukcyjne w ramach projektu zostały doposażone $\mathrm{w}$ umundurowanie i uzbrojenie $\mathrm{z}$ epoki $\mathrm{w}$ postaci wiernych replik. Odbyły się edukacyjne „żywe lekcje historii” dla dzieci i młodzieży 
(Standardowy wniosek... Rekonstrukcje historyczne... 2008). Projekt „Fortfan" miał na celu przede wszystkim rozwijanie nieformalnych więzi międzyludzkich, oddolnych inicjatyw społecznych oraz wspieranie współpracy instytucji i organizacji działających na pograniczu. Blisko czteroletnie kontakty w ramach projektu zaowocowały stałą współpracą między poszczególnymi gminami partnerami, a także licznymi stowarzyszeniami rekonstrukcyjnymi działającymi na pograniczu polsko-czeskim (KRAWCZYSZYN 2011). Kilku spośród partnerów projektu marki „Fortfan” (Kłodzko, Stoszowice, Świdnica) realizuje już nowe projekty ukierunkowane na organizację kolejnych historycznych widowisk w swoich miastach. Jednocześnie gminy utrzymują tradycje związane $\mathrm{z}$ organizacją wymienionych imprez edukacyjno-rekreacyjnych również ze środków własnych, bez wsparcia zewnętrznego, co wynika m.in. z obowiązku utrzymania pięcioletniego okresu tzw. trwałości projektu.

\section{Sieciowy produkt turystyczny pogranicza polsko-czeskiego}

Sieciowe inicjatywy turystyczne na pograniczu polsko-czeskim coraz częściej zyskują popularność. Zrealizowano już około 800 projektów polsko-czeskich, których głównym celem był rozwój turystyki lub dziedzin okołoturystycznych (kultura, sport, edukacja, ochrona środowiska). Spośród nich przeważającą część stanowiły projekty dwustronne (jeden partner polski i jeden partner czeski), jednak zdarzały się także projekty trójstronne i wielostronne, tak jak analizowane powyżej projekty budujące marki "Citywalk" i „Fortfan” (odpowiednio sześciu i dziewięciu partnerów). Ze względu na rozbudowany charakter sieci i ciekawe założenia koncepcyjne, projekty te należą do czołówki zrealizowanych z sukcesem polsko-czeskich projektów EWT w okresie programowania 2007-2013. Projekt „Miejskie trasy turystyczne zintegrowanym produktem turystycznym polsko-czeskiego pogranicza" został uhonorowany wyróżnieniem w plebiscycie Ministerstwa Rozwoju Regionalnego pt. „Polska Pięknieje - 7 Cudów Funduszy Europejskich”, jako przykład dobrych praktyk w realizacji tego typu przedsięwzięć. Celem konkursu jest wyłonienie najlepszych projektów, które przyczyniły się do podniesienia turystycznej i kulturalnej atrakcyjności Polski. 


\section{Podsumowanie}

Nowe produkty turystyczne wywołują zmiany oferty turystycznej pogranicza polsko-czeskiego zasadniczo w dwóch kierunkach: unifikacji i dywersyfikacji. Przykłady sieci turystycznych stworzonych pod szyldami "Citywalk” i „Fortfan” wskazują, że unifikacja oferty czesko-polskiego pogranicza jest $\mathrm{w}$ pewnym stopniu możliwa, jednak tego typu projekty realizowane są rzadko. Tylko tworzenie zaawansowanych sieciowych produktów turystycznych o szerokim zasięgu przestrzennym dałoby możliwość zunifikowania pogranicza polsko-czeskiego jako jednolitego regionu turystycznego. Z kolei dywersyfikacji oferty pogranicza sprzyja tworzenie licznych i bardzo zróżnicowanych produktów turystycznych promowanych oddzielnie i obejmujących wąski obszar (brak identyfikacji produktu z pograniczem polsko-czeskim jako całością, a raczej z konkretnym obiektem, gminą czy miejscowością). Tego typu projektów turystycznych, także realizowanych przy wsparciu środków pomocowych UE, jest znacznie więcej.

Z punktu widzenia aktualnych trendów w turystyce europejskiej coraz większą rolę w świadomości klientów odgrywają produkty złożone: pakietowe, sieciowe, stanowiące jednolitą i kompletną całość. $Z$ tego powodu traktowanie pogranicza polsko-czeskiego jako spójnego regionu turystycznego, który mimo podzielenia granicą państwową posiada jednolite walory turystyczne i dąży do podobnego poziomu zagospodarowania turystycznego (konwergencja), może okazać się w przyszłości uzasadnione. Z drugiej strony koordynacja całościowego produktu turystycznego pogranicza nie jest aktualnie możliwa. Nie istnieje jednostka, której zadaniem byłoby zarządzanie kierunkami rozwoju turystyki na pograniczu polsko-czeskim $\mathrm{w}$ taki sposób, aby rozwijało się ono spójnie a poszczególne realizowane projekty byłyby wobec siebie komplementarne. Namiastkę tej roli stanowią instytucje pośredniczące w przyznawaniu środków pomocowych, jednak robią to jedynie poprzez wskazywanie w priorytetach i wytycznych rodzajów projektów, które mogą otrzymać dofinansowanie. Samorządy lokalne pogranicza Republiki Czeskiej i Rzeczypospolitej Polskiej już od lat współpracują w celu stworzenia nowej jakości oferty turystycznej. Otwartą kwestią pozostaje pytanie, czy po zakończeniu programów wspierających rozwój Europejskiej Współpracy Terytorialnej, a co za tym idzie przy braku finansowych czynników motywujących do zawiązywania współpracy, polsko-czeska współpraca transgraniczna $\mathrm{w}$ dziedzinie turystyki będzie nadal dynamicznie się 
rozwijała i generowała zaawansowane produkty sieciowe podobne do marek „Citywalk” i „Fortfan”?

\section{BIBLIOGRAFIA}

KRAWCZYSZYN N., 2012, Rozwój sieciowy na pograniczu polsko-czeskim - euroregionalny produkt turystyczny, "Barometr Regionalny. Analizy i Prognozy”, 2 (28), M. Kowerski (red.), Wyższa Szkoła Zarządzania i Administracji, Zamość, s. 123-128.

KRAWCZYSZYN N., 2011, Turystyczne marki "Citywalk” i „Fortfan” jako przykład transgranicznej wspótpracy sieciowej, [w:] Gospodarka przestrzenna, A. Dybała, J. Potocki (red.), Prace Naukowe Uniwersytetu Ekonomicznego we Wrocławiu, 240, UE we Wrocławiu, s. 58-67.

PANASIEWICZ Z., 1999, Euroregiony na granicach Polski, [w:] Euroregiony w nowym podziale terytorialnym Polski, H. Dmochowska (red.), GUS, Wrocław, s. 203-204.

PANASIUK A., 2006, Wspótpraca samorządu terytorialnego i przedsiębiorstw turystycznych - zagadnienia instytucjonalne, [w:] Gospodarka turystyczna w regionie. Przedsiębiorstwo. Samorząd. Wspótpraca, A. Rapacz (red.), Wyższa Szkoła Zarządzania Gospodarką Regionalną i Turystyką w Kielcach, Jelenia Góra.

Program Operacyjny Współpracy Transgranicznej Republika Czeska - Rzeczpospolita Polska. 2007-2013: http:/ / www.cz-pl.eu/index.php?cmd=show\&imageID=14\&title=; 25.01.2011 r.

Serwis internetowy Science meets business; 29.04 .2013 r.; http://www.zarzadzanie.net.pl/ przeglad_definicji_koopetycja_kooperencja.html.

Serwis internetowy rekonstrukcji historycznych „Fortfan”, http://fortfan.eu/; 20.11.2013 r.

Serwis internetowy miejskich tras turystycznych "Citywalk", http://citywalk.info/; 20.11. $2013 \mathrm{r}$.

Standardowy wniosek o przyznanie dofinansowania z Programu Operacyjnego Współpracy Transgranicznej 2007-2013 republika Czeska - Rzeczpospolita Polska, tytuł projektu: Miejskie trasy turystyczne zintegrowanym produktem turystycznym miast czesko-polskiego pogranicza, ze zbiorów Urzędu Miejskiego w Świdnicy, 2008.

Standardowy wniosek o przyznanie dofinansowania z Programu Operacyjnego Współpracy Transgranicznej 2007-2013 Republika Czeska - Rzeczpospolita Polska, tytuł projektu: Rekonstrukcje historyczne wspólnym produktem turystycznym polsko-czeskiego pogranicza, ze zbiorów Urzędu Miejskiego w Świdnicy, 2008, s. 16-17.

SzOSTAK D., 2006, Klaster jako narzędzie podnoszenia konkurencyjności i innowacyjności regionalnej gospodarki turystycznej, [w:] Gospodarka turystyczna w regionie. Przedsiębiorstwo. Samorząd. Wspótpraca, A. Rapacz (red.), Wyższa Szkoła Zarządzania Gospodarką Regionalną i Turystyką w Kielcach, Jelenia Góra 2006. 